\begin{tabular}{ll} 
Homepage: http:/jusami.batan.go.id & Jurnal Sains Materi Indonesia \\
\hline & $\begin{array}{l}\text { Akreditation No : 36/E/KPT/2019 } \\
\text { ISSN 14 Dec 2019 } \\
\text { E-ISSN 2614-087X }\end{array}$ \\
\hline
\end{tabular}

\title{
EFFECTS OF CHITOSAN COATING ON THE PHYSICAL, MECHANICAL AND ANTIMICROBIAL PROPERTIES OF FOOD PACKAGING PAPER
}

\section{Kurnia Wiji Prasetiyo ${ }^{1}$, Deni Zulfiana ${ }^{1}$, Sita Heris Anita ${ }^{1}$, Widya Fatriasari, Lisman Suryanegara ${ }^{1}$, Nanang Masruchin ${ }^{1}$ and Sesmi Gutari ${ }^{2}$}

\author{
${ }^{1}$ Research Center for Biomaterials - Indonesian Institute of Sciences (LIPI) \\ Jl. Raya Bogor Km. 46 Cibinong Bogor \\ ${ }^{2}$ Department of Chemistry, Faculty of Mathematics and Natural Sciences - IPB \\ Jl. Tanjung Kampus IPB Dramaga Bogor \\ E-mail:jundiazzam@yahoo.com
}

Received: 5 October 2019

Revised: 28 December 2019

Accepted: 10 January 2020

\begin{abstract}
EFFECTS OF CHITOSAN COATING ON THE PHYSICAL, MECHANICAL AND ANTIMICROBIAL PROPERTIES OF FOOD PACKAGING PAPER. The coating process on food packaging paper is carried out to improve the food safety and health aspect from dangerous substance migration from food packaging into food. Chitosan has attracted interest in packaging, especially in food packaging as edible films and coatings. A paper from oil palm empty fruit bunches (OPEFB) pulp was coated with chitosan using different pulp weight $(1,1.5,2 \mathrm{~g})$ and chitosan content $(0.25,0.50,0.75,1 \mathrm{~g})$ as parameters. The effect of chitosan as coating material on physical, mechanical, and antimicrobial properties was studied. The results showed that the density and grammage values of the paper increased after coating due to the increasing of chitosan content. The mechanical properties of the coated paper, such as tensile strength, tensile modulus and elongation, improved in line with the increase of chitosan content and pulp weight. The addition of chitosan on paper imparts antimicrobial properties against Gram-positive bacteria (Staphylococcus aureus) and Gramnegative bacteria (Escherichia coli).
\end{abstract}

Keywords: Antimicrobial, Chitosan, Coating, Paper, OPEFB

\begin{abstract}
ABSTRAK
EFEK PELAPISAN KITOSAN TERHADAP SIFAT FISIK, MEKANIK DAN MIKROBA DARI KERTAS KEMASAN PANGAN. Proses pelapisan pada kertas kemasan makanan dilakukan untuk meningkatkan aspek keamanan dan kesehatan makanan dari migrasi zat berbahaya dari kemasan makanan ke makanan. Kitosan telah menarik minat dalam pengemasan, terutama dalam pengemasan makanan sebagai edibel film dan pelapis. Kertas dari pulp tandan kosong kelapa sawit (TKKS) dilapisi dengan kitosan dengan menggunakan perbedaan berat pulp $(1,1.5,2 \mathrm{~g})$ dan kandungan kitosan $(0.25,0.50,0.75,1 \mathrm{~g})$ sebagai parameter. Efek kitosan sebagai bahan pelapis terhadap sifat fisik, mekanik, dan antimikroba telah dipelajari. Hasil penelitian menunjukkan bahwa nilai kerapatan dan gramatur kertas meningkat setelah pelapisan karena meningkatnya kandungan kitosan. Sifat mekanis kertas yang dilapisi, seperti kekuatan tarik, modulus tarik dan elongasi, meningkat seiring dengan peningkatan kandungan kitosan dan berat pulp. Penambahan kitosan pada kertas memberikan sifat antimikroba terhadap bakteri Gram-positif (Staphylococcus aureus) dan bakteri Gram-negatif (Escherichia coli).
\end{abstract}

Kata kunci: Antimikroba, Kitosan, Pelapisan, Kertas, TKKS 


\section{INTRODUCTION}

Food packaging technology is growing rapidly, along with the development of human science and civilization. At the end of the nineteenth century, industrial revolution results in the mass production of goods and transportation to consumers who also led to the need for appropriate materials that satisfy the criteria for a successful packaging [1]. The criteria for a successful packaging includes the product, protect goods from mechanical damage, preserve products from deterioration, inform the consumer, and provide visual impacts [2].

Among the materials for food packaging that are common and widely used today are paper. Data in 2012 indicated that the use of paper and paperboard for packaging materials reached $36 \%$ of the total need for packaging materials [3] while, the consumption of food packaging paper in Indonesia is around 90.000-100.000 tons/year [4].

Food packaging paper has advantages such as light, inexpensive, easy to store, and recycle compared to other packaging. However, packaging paper is easy to tear, flammable, heat un-resistance but it can't be used to package liquids. In general, the basic material of packaging paper is pulp, which produced from wood or non-wood fiber. Currently, there are many forms of paper for food packaging, such as boxes, cups, bags, wrappings, multilayer carton boxes and folding cartons available on the market. They are used for packaging various food products, including flour, cookies, biscuits, cereals, rice, chocolate, or nuts. However, due to its inherent features, the packaging paper results from highly porous cellulose structure paper is highly permeable to gases, has high hygroscopic properties and lower than plastics resistance to moisture and oil. Based on these features, the use of paper as a packaging material does not apply to all food products. Applying an additional layer of paraffin-based coatings could eliminate these drawbacks $[5,6,7]$.

Commercial rice packaging paper (brown color) made from recycled paper has not had safe yet for human health. The number of bacteria content in food paper made from recycled paper is around 1.5 million colonies per gram, while the average commonly used rice paper weight 70-100 grams, which means there are as many as 105-150 millions bacteria found on the rice wrapping paper. This value exceeds the specified limit [8].

The enhancement of public awareness about the importance of health and sustainable environment encourage research and development of packaging materials technology that is healthier and environmentally friendly. When designing, producing, and handling food products, one of the most important aspects is ensuring food safety and consumers. As mentioned above, the paper is a widely available material, relatively easy to recycle; therefore, it is suitable for sustainable packaging solutions. On the other hand, the use of recycled paper for food paper packaging results in serious contamination problems because of dangerous substance migration. However, some disadvantageous properties of paper can be eliminated by coating or impregnating $[9,10]$.

In general, bio-based polymers are mostly used as coatings on papers, cardboards, boards with different coating techniques (solution coating, surface sizing, curtain coating, compression moulding). At polysaccharides, mostly used are chitosan, starches (rice, wheat maize, corn and potato) and alginates. They have great properties such as non-toxicity, can be used in many fields of material science, and are available in the market also as waste materials [11]. Polysaccharides with great gas, aroma, and grease barriers, such coatings have great potential in packaging materials. Because of their hydrophilic nature, polysaccharides exhibit poor water vapor barrier [12].

Chitosan is one of the most non-toxic and commonly used polysaccharide, which is derived from the deacetylation of chitin [12]. Chitosan is able to bind water and oil because it has polar and non-polar groups [13]. Chitosan has also attracted interest in packaging, especially in food packaging as edible films and coatings $[14,15]$.

The usage of paper as food packaging materials is likely to increase in the future as more nations shift toward a circular economy that favors bio-based materials and reduces waste. Paper coatings used in packaging must meet requirements such as high barrier and mechanical properties, good antimicrobial stability, simple production technology and low costs. Therefore, this research was done to determine the effects of chitosan coating on the physical, mechanical, and antimicrobial properties of food packaging paper from oil palm empty fruit bunches (OPEFB) pulp. The parameters in this study were the weight of chitosan and pulp weight.

\section{EXPERIMENTAL METHOD}

\section{Materials and Instruments}

The unbleached pulp of oil palm empty fruit bunches (OPEFB) was processed at the Bandung Pulp and Paper Center using kraft pulping process. Industrial grade chitosan from shrimp shells was obtained from PT Biotech Surindo Cirebon. Escherichia coli ATCC 8739 (a type of Gram-negative bacteria), Staphylococcus aureus ATCC 6538 (a type of Gram-positive bacteria), Candida albicans (yeast) were obtained from IPBCC (IPB Culture Collection) and Aspergillus niger A1100F003A (fungi) was obtained from Indonesia Culture Collection (InaCC). Nutrient Agar (NA), Potato Dextrose Agar (PDA), Nutrient Broth (NB), and Potato Dextrose Broth (PDB) were used for microbial culture and 
purchased from Difco. The equipments was used include OHAUSS digital balance, beaker glass, Erlenmeyer flasks, autoclaves, laminar air flow, hot plate stirrer, magnetic stirrers, oven, laboratory blenders, plastics, plastic trays, spoons, Mitutoyo digital calipers and Universal Testing Machine (UTM) type AG-IS $50 \mathrm{kN}$ merk SHIMADZU.

\section{Preparation of Samples}

Unbleached pulp of OPEFB was weighed in 3 variations i.e $1 \mathrm{~g}, 1.5 \mathrm{~g}$ and $2 \mathrm{~g}$. The weighed pulp then soaked at beaker glass using water until the texture becomes soft and easy to mix. The soaked pulp was then processed using a laboratory blender for 1 minute until the pulp becomes completely smooth and fibrillated.

The next stage was to prepare chitosan solution by dissolving using $0.5 \% \mathrm{v} / \mathrm{v}$ acetic acid solution. The variation of chitosan weight was $0.25 \mathrm{~g}, 0.50 \mathrm{~g}, 0.75 \mathrm{~g}$ and $1 \mathrm{~g}$. Chitosan solution was stirred by a hot plate stirrer at room temperature until completely dissolved.

\section{Manufactured of Paper Coated Chitosan}

The process of making paper carried out the formation of sheets one by one. In this study twentyfour sheets of paper were made with variations in pulp weight and chitosan weight. The unbleached pulp of OPEFB that has been mashed and chitosan solution were mixed using laboratory blender again for 40 seconds until evenly mixed. The mixture of chitosan and pulp solution were weighed and cast on a plastic tray with size $22.5 \mathrm{~cm}$ $\mathrm{x} 18 \mathrm{~cm}$ x $4 \mathrm{~cm}$. Then the sample was dried at $60^{\circ} \mathrm{C}$ for 24 hours until it dries.

\section{Testing of Paper Coated Chitosan}

The characteristics of paper coated chitosan were tested, including the gravimetric physical properties such as density and paper grammage. The mechanical properties were tensile strength, tensile modulus and elongation at break. The dried paper was cutted in size of $10 \mathrm{~cm} \times 2.5 \mathrm{~cm}$ (5 sample test per paper sheet). Antimicrobial activities of paper coated with chitosan was measured according to the disc diffusion method with a slight modification in the medium [16].

Escherichia coli (a type of Gram-negative bacteria), Staphylococcus aureus (a type of Grampositive bacteria), Candida albicans (yeast), Aspergillus niger (fungi) were used in testing of the antimicrobial activities. One to two loop of microorganism was inoculated into $50 \mathrm{~mL}$ of culture medium in $100 \mathrm{~mL}$ Erlenmeyer flask. The culture medium was nutrien broth (NB) and potato dextrose broth (PDB) for bacteria and yeast/fungi, respectively. The flask was incubated in rotary shaker $(120 \mathrm{rpm})$ for $24 \mathrm{~h}$ at room temperature $\left(30 \pm 2{ }^{\circ} \mathrm{C}\right)$. At the end of the incubation period, $1 \%(\mathrm{v} / \mathrm{v})$ of inoculum (approximately
$10^{7} \mathrm{CFU} / \mathrm{mL}$ ) was inoculated into $200 \mathrm{~mL}$ of agar medium and mixed until homogen by using magnetic stirrer. As much as $20 \mathrm{~mL}$ of the mixtures were then poured into sterilized petri dish. After solidification, circular samples of the coated papers (diameter $8.0 \mathrm{~mm}$ ) were placed on the surface of agar. The dishes were then incubated at room temperature for $24-48 \mathrm{~h}$.

The antimicrobial activity was evaluated by measuring the diameter of inhibition zones. As a comparison, three kinds of commercial rice packaging paper with variation of grammage from the market were also tested.

\section{RESULTS AND DISCUSSION}

\section{The Physical Properties}

The physical properties of the papers were tested include density and grammage. The density value of coated paper was presented in Fig. 1. The density was ranging from 0.12 to $0.23 \mathrm{~g} / \mathrm{cm}^{3}$. The content of chitosan increases the density of papers, but the increment was insignificant while the content of pulp increases the density of papers. The slight increase of coated paper density may be related to the penetration of chitosan solution into the cellulose network.. However, increasing of pulp content actually is vice versa The highest density value was obtained on the highest chitosan content of coated paper is $0.75 \mathrm{~g}$ with a pulp weight of $2 \mathrm{~g}$. While, the density of 3 kinds of commercial rice packaging paper with poly ethylene (PE) are $0.59,0.52$ and $0.62 \mathrm{~g} / \mathrm{cm}^{3}$. It means that the paper was coated chitosan is lighter than commercial paper samples.

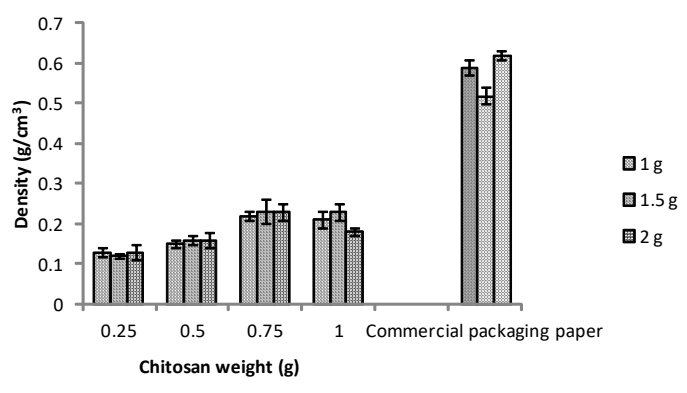

Figure 1. Density value of papers coated chitosan.

The ease of paper-making materials to mix will affect the level of homogeneity of the mixture, which ultimately affects the density value. Increasing of density value from papers along with the amount of chitosan coated in line with the properties of chitosan. It is able to increase the growth power when combined with other materials [17].

Paper grammage is the amount of paperweight per unit area in grams per square meter. Some types of paper have different grammage values according to their intended use. In general, the chitosan coated paper has various grammage values shown in Fig. 2. In general, 


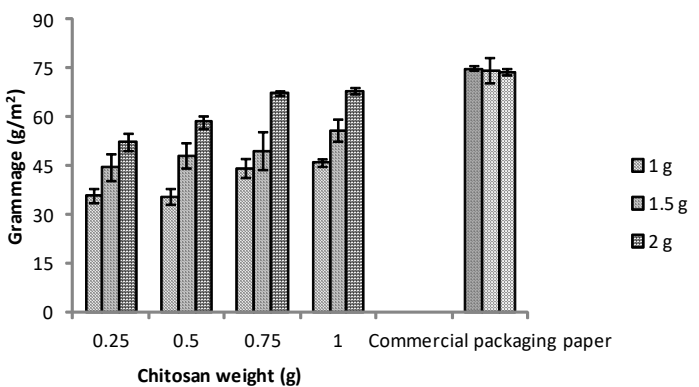

Figure 2. Grammage value of paper coated chitosan.

the grammage of paper made from $1.5 \mathrm{~g}$ pulp and coated chitosan $1 \mathrm{~g}$ were statistically higher than those of paper coated with less chitosan and pulp also compared to commercial packaging paper. This condition was occurred because this paper had the highest density. This is probably caused by the effect of paperweight, where the higher of paper weight result in higher value of the paper grammage. Because the paper surface area is relatively identical, paper grammage determination is very important. Paper weight affects the physical, mechanical, chemical, and optical properties [18].

Standard of SNI 8218: 2015 concerns about food packaging paper [19], requires a minimum value of food packaging grammage is $26 \mathrm{~g} / \mathrm{m}^{2}$. The chitosan coated paper which was prepared has a grammage value ranging from $35.61-77.42 \mathrm{~g} / \mathrm{m}^{2}$. It can indicate that chitosan coated paper from unbleached OPEFB pulp has met the SNI 8218: 2015 standard.

Even though, OPEFB pulp contains mostly short fiber, the grammage of chitosan coated paper has meet the standard for paper packaging. Based on the analysis, variations in chitosan and pulp weight were influenced value of the food packaging paper grammage which manufactured. The combination of curdlan biopolymer and chitosan as a coating on packaging paper can increase density and grammage [11]. Habibie et al. [20] studied that the grammage values of the control sample and paper sheet coated with $1 \%(\mathrm{w} / \mathrm{w})$ of chitosan were similar, but the coated paper sheet had lower water absorption. However, the sample treated with $1 \%$ of chitosan and $20 \%$ of filler presented higher grammage but a slightly lower water absorption.

\section{Mechanical Properties}

The mechanical properties of the paper are tested to determine the ability of the paper to maintain its state until it does not break when paper is stretched and given a tensile force on both ends of the paper. The paper samples were measured in standard conditions. The calculated value includes tensile strength, tensile modulus and paper elongation. The above values are important in determining the ability of paper to function properly as packaging paper. Value of tensile strength, tensile modulus and paper elongation is showed sequentially in Fig. 3, 4 and 5.
The tensile strength (TS) of coated paper with various content of chitosan is shown in Fig. 3. The TS value of papers enhanced in line with the addition of chitosan as coating material on papers (ranging from 0.89 to $5.9 \mathrm{MPa}$ ) until chitosan content $0.75 \mathrm{~g}$ and decreased slightly. However, the addition of pulp weight as paper raw materials decreased TS values The higher TS of paper was obtained from combination between chitosan $0.75 \mathrm{~g}$ and $1 \mathrm{~g}$ pulp weight is $5.9 \mathrm{MPa}$. It is higher than that of the tensile strength of 1 type of commercial packaging paper (4.47 $\mathrm{MPa}$ and other compositions).

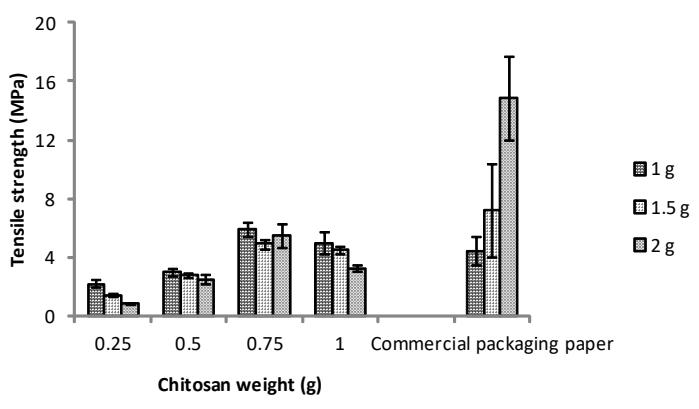

Figure 3. Tensile strength from paper coated chitosan.

The tensile modulus (TM) values also show the similar trend as the tensile strength values of paper. The more chitosan as a paper coating material tends to increase the TM which maximum at $0.75 \mathrm{~g}$ chitosan then decreased slightly. While the addition of pulp weight decreases the TM of the paper. The TM on the paper is ranging from 44.21 to $369.63 \mathrm{MPa}$ as shown in Fig. 4. These values are still below to the tensile modulus value of 3 types commercial packaging paper.

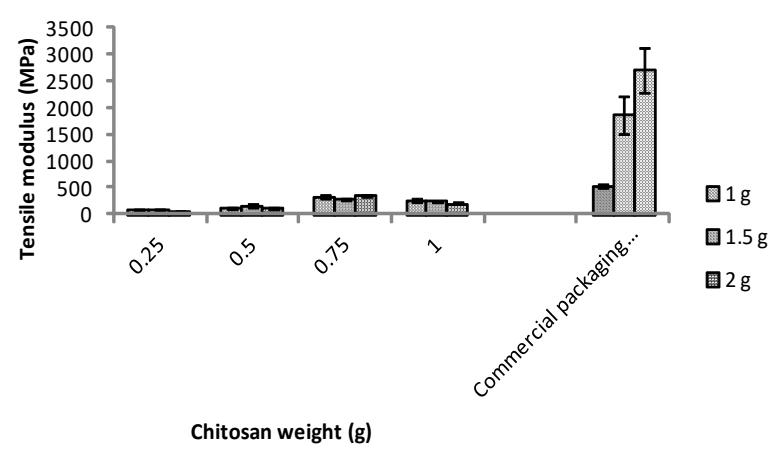

Figure 4. Tensile modulus value of paper coated chitosan.

Generally, the presence of chitosan as a coating on paper also is able to increase the elongation at break (E) of coated paper. The $\mathrm{E}$ value begins to show an increase start from chitosan weight of 0.25 to $1 \mathrm{~g}$. The addition of chitosan increases the $\mathrm{E}$ of papers, but the increment was insignificant, while the content of pulp increases the $E$ of papers as shown in Fig 5. The E value of paper is ranging from $2.69-6.87 \%$ which turned out that the value is higher than that of the elongation at 


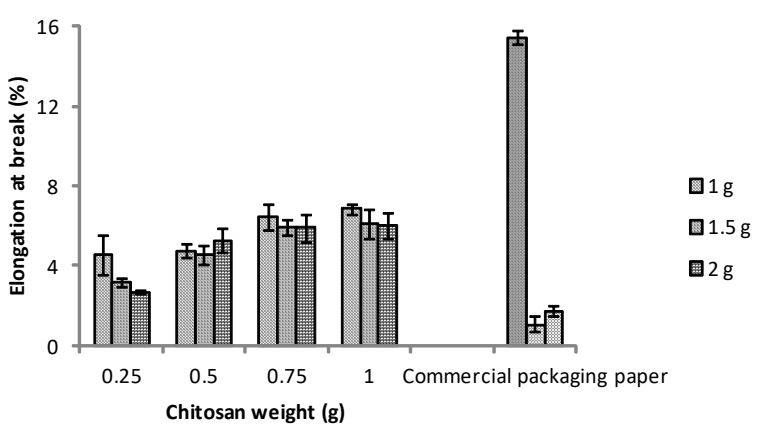

Figure 5. Elongation value of paper coated chitosan.

break of 2 types of commercial packaging paper i.e. 1.1\% and $1.7 \%$.

The presence of chitosan as a coating on food packaging paper has proven to improve and enhance the mechanical properties of paper. The good interface with molecular interactions between fibers can improve tensile strength and elongation from paper packaging [21]. The TM and E values also related with the rigidity of paper. The increasing of pulp amount increased the rigidity of paper which results in a decrease of TM and E values. The more chitosan as coating materials tends to increase the tear strength that caused the papers were not more easily to tear and improved the TM and E values. Tear strength that related to tensile strength, tensile modulus and elongation at break indicates the behavior of paper and it is important in packaging papers, where the toughness and shock absorption are very important factors. The fact is that fillers and additives improve tear strength, as it tends to distribute the stress over the whole overlong, cellulose fibers in the paper [11]. The decreased tensile strength and elastic modulus/tensile modulus of PBAT-coated Kraft paper coated using high numbered coating bars was presumably due to that the mechanical strength and rigidity of the coated paper was influenced more by the flexible PBAT films than the base Kraft paper [22]

\section{Antimicrobial Activity}

Antimicrobial activities of food packaging paper from OPEFB pulp coated chitosan were studied by disc diffusion method againts Gram negative bacteria (Escherichia coli), Gram positive bacteria (Staphylococcus aureus), yeast (Candida albicans), and also fungi (Aspergillus niger). Almost samples tested showed growth inhibition zone againts Escherichia coli and Staphylococcus aureus after $24 \mathrm{~h}$ incubation compared to commercial rice packaging paper. The results of the inhibition zone of microbial growth are presented in Table 1.

In this present study, bacterial strains showed more sensitive to chitosan than the yeast or fungi strain. It can be caused due to different type of organism and cell wall constituent. Kong et al. [23] explained that bacteria was less sensitive to the antimicrobial action of chitosan than that of fungi. Although chitosan was a broad spectrum of antimicrobial activity, its inhibitor efficiency againts different fungi and bacteria was also differ.

Table 1. Antimicrobial activity of food packaging paper from oil palm empty fruit bunches pulp coated chitosan.

\begin{tabular}{ccccc}
\hline \multirow{2}{*}{ Sample } & \multicolumn{4}{c}{ Zone of inhibition (mm) } \\
\cline { 2 - 5 } & E. coli & S. aureus & C. albicans & A. niger \\
\hline Pulp of OPEFB & - & - & - & - \\
Chitosan & - & - & - & - \\
A & $10.0 \pm 0.0$ & - & - & - \\
B & $10.0 \pm 0.0$ & $9.0 \pm 0.10$ & - & - \\
C & $8.3 \pm 0.03$ & $8.7 \pm 0.10$ & - & - \\
D & $9.3 \pm 0.07$ & - & - & - \\
K1 & - & - & - & - \\
K2 & - & - & - & - \\
K3 & - & - & - & - \\
\hline
\end{tabular}

Remarks:

A: paper coated chitosan $0.25 \mathrm{~g}$

B: paper coated chitosan $0.50 \mathrm{~g}$

C: paper coated chitosan $0.75 \mathrm{~g}$

D: paper coated chitosan $1 \mathrm{~g}$

K1: commercial packaging paper code 1

K2: commercial packaging paper code 2

$\mathrm{K} 3$ : commercial packaging paper code 3

Table 1 also showed that Gram-positive bacteria (S. aureus) is more resistant than Gram-negative bacteria (E. coli). One of the reasons for the antimicrobial character of chitosan is it's positively charged amino group, which interacts with negatively charged microbial cell membranes. That interaction disrupted the normal functions of the membrane by promoting the leakage of intracellular components or by inhibiting the transport of nutrients into cells. It was reported that the negative charge on the cell surface of Gramnegative bacteria was higher than that on Gram-positive bacteria [24,25].

The result showed that the increased concentration of chitosan did not give the higher inhibition effect. It might be caused due to the imperfect mixing of chitosan and pulp solution in the making paper process. However, Goy et al. [26] indicated that the antibacterial effectiveness of chitosan was significantly affected by its applied concentration.

Generally, all variation of samples with coated chitosan has a antimicrobial activity compared to commercial packaging paper. It means, chitosan potential to be used as coating material at food packaging paper.

\section{CONCLUSION}

The properties of food packaging paper from OPEFB pulp coated with chitosan are determined. Chitosan proves to be a coating material used at paper 
for food packaging paper. In general, the physical and mechanical properties of the coated paper are enhanced and improved by increasing chitosan weight. The food packaging paper coating chitosan of $0.75 \mathrm{~g}$ has the best mechanical properties. Chitosan as a coating material at paper has proven to be able to inhibit microbial activity compared to commercial rice packaging paper.

\section{ACKNOWLEDGMENT}

This research was supported by Research Incentive of National Innovation System (INSINAS) 2019 from The Ministry of Research and Higher Education (KEMENRISTEKDIKTI).

\section{REFERENCES}

[1]. R. C. Griffin, S. Sacharow, and A. L. Brody, Principles of Package Development. Springer Netherlands, 1985.

[2]. M. J. Kirwan, "Paper and Paperboard Packaging," in Food and Beverage Packaging Technology: Second Edition, Wiley-Blackwell, 2011, pp. 213250.

[3]. D. Raheem, "Use and Production of Paper Packaging for Food," in Reference Module in Food Science, Elsevier, 2016.

[4]. D. A. Indrawan, L. Efiyanti, R. M. Tampubolon, and H. Roliadi, "The manufacture of pulp for wrapping paper from alternative fiber stuffs," J. Penelit. Has. Hutan, vol. 33, no. 4, pp. 283-302, 2015.

[5]. Z. Berk, Food Process Engineering and Technology. Elsevier Inc., 2009.

[6]. L. J. Mauer and B. F. Ozen, "Food Packaging," Food Processing. pp. 101-131, 06-Jul-2004.

[7]. J. W. Rhim, "Effect of moisture content on tensile properties of paper-based food packaging materials," Food Sci. Biotechnol., vol. 19, no. 1, pp. 243-247, 2010.

[8]. L. Suryanegara. "Kemananan kemasan pangan dari kertas daur ulang." Laporan Riset Kerjasama, Pusat Penelitian Biomaterial LIPI Cibinong, 2016.

[9]. H. Aloui and K. Khwaldia, "Effects of coating weight and nanoclay content on functional and physical properties of bionanocomposite-coated paper," Cellulose, vol. 24, p. 44934507, 2017.

[10]. M. Nowacka et al., "Application of various types of coatings in food packaging materials: Sensorial assessment and health safety," J. Process. Energy Agric., vol. 21, no. 2, pp. 71-75, 2017.

[11]. U. V. Brodnjak, "Experimental investigation of novel curdlan/chitosan coatings on packaging paper," Prog. Org. Coatings, vol. 112, pp. 86-92, 2017.
[12]. N. Bordenave, S. Grelier, and V. Coma, "Hydrophobization and antimicrobial activity of chitosan and paper-based packaging material," Biomacromolecules, vol. 11, pp. 88-96, 2010.

[13]. M. Tülsner, "M. WINDSOR und S. BARLOW: Introduction to fishery by-products. 187 Seiten, 52 Abb., 17 Tab. Fishing News Books Ltd., Farnham, Surrey, England, 1981. Preis: 13.50 £.," Food / Nahrung, 1982.

[14]. N. Bordenave, S. Grelier, F. Pichavant, and V. Coma, "Water and moisture susceptibility of chitosan and paper-based materials: Structure-property relationships," J. Agric. Food Chem., vol. 55, pp. 9479-9488, 2007.

[15]. Y. X. Xu, K. M. Kim, M. A. Hanna, and D. Nag, "Chitosan-starch composite film: Preparation and characterization," Ind. Crops Prod., vol. 21, pp. 185-192, 2005.

[16]. J. Ma, W. Zhu, Y. Tian, and Z. Wang, "Preparation of Zinc Oxide-Starch Nanocomposite and Its Application on Coating," Nanoscale Res. Lett., 2016.

[17]. K.W. Prasetiyo. "Polypropylene Substitution by Chitosan on Polypropylene-Empty Fruit Bunch Fiber of Oil Palm Microfibril Termoplastic Composites. M.A, thesis, Bogor Agricultural University, Bogor, 2012.

[18]. J. P. Casey, "Pulp and Paper, Chemistry and Chemical Technology, Volume I.," Bioresour. Technol., vol. 101, no. 13, pp. 4744-4753, 1980.

[19]. National Standarisation Agency of Indonesia (BSN). Indonesian National Standard (SNI) 8218:2015 Paper and paperboard for food packaging.

[20]. H. S, H. M, A. M, and K. E, "The effect of chitosan on physical and mechanical properties of paper," J. Chem. Eng. Mater. Sci., vol. 7, no. 1, pp. 1-10, 2016.

[21]. K. Khwaldia, A. H. Basta, H. Aloui, and H. El-Saied, "Chitosan-caseinate bilayer coatings for paper packaging materials," Carbohydr. Polym., vol. 99, pp. 508-516, 2014.

[22]. S. Shankar and J. W. Rhim, "Effects of poly(butylene adipate-co-terephthalate) coating on the water resistant, mechanical, and antibacterial properties of Kraft paper," Prog. Org. Coatings, vol. 123, pp. 153-159, Oct. 2018.

[23]. M. Kong, X. G. Chen, K. Xing, and H. J. Park, "Antimicrobial properties of chitosan and mode of action: A state of the art review," Int. J. Food Microbiol., vol. 144, pp. 51-63, 2010.

[24]. W. L. Du, Y. L. Xu, Z. R. Xu, and C. L. Fan, "Preparation, characterization and antibacterial properties against E. coli K88 of chitosan nanoparticle loaded copper ions," Nanotechnology, vol. 19, pp. 1-5, 2008. 
[25]. L. Karam, C. Jama, P. Dhulster, and N. E. Chihib, "Study of surface interactions between peptides, materials and bacteria for setting up antimicrobial surfaces and active food packaging," J. Mater. Environ. Sci., vol. 4, no. 5, pp. 798-821, 2013.
[26]. R. C. Goy, S. T. B. Morais, and O. B. G. Assis, "Evaluation of the antimicrobial activity of chitosan and its quaternized derivative on E. Coli and S. aureus growth," Brazilian J. Pharmacogn., vol. 26, no. 1,pp. 122-127, 2016. 